\title{
Studies on Conditions Favouring Sclerotial Propagules Infection and Effect of Botanical Extracts on its Production and Growth in Sclerotium oryzae
}

\author{
Vandana Sahu $^{1,2^{*}}$ and V.S. Thrimurthy ${ }^{1}$ \\ ${ }^{1}$ Department of Plant Pathology, College of Agriculture, IGKV, Raipur, India \\ ${ }^{2}$ Department of Mycology and Plant Pathology, Institute of Agricultural Sciences, \\ Banaras Hindu University, India \\ *Corresponding author
}

\section{A B S T R A C T}

\begin{tabular}{|l|}
\hline K e y w o r d s \\
Sclerotial \\
propagules, \\
Sclerotium oryzae, \\
Botanical extracts, \\
Growth \\
\hline Article Info \\
\hline $\begin{array}{l}\text { Accepted: } \\
\text { 12 July 2019 } \\
\text { Available Online: } \\
\text { 10 August } 2019\end{array}$ \\
\hline
\end{tabular}

Rice is one of the major grains of the India and also significant part of national economy. Its production is severely affected by various biotic and abiotic stresses. Among different fungal disease stem rot of rice caused by Scleoritina oryzae leads to great losses. Under adverse conditions sclerotia are formed and act as main source of primary inoculum till the other collateral or/and alternate hosts appearance in the vicinity. Thus the present study is to know the best conditions that favour the sclerotial infection after the perpetuation. We took a highly susceptible variety and inoculated the sclerotia in three different ways: first, one sclerotium per sheath with transparent tape piece. Second, the sclerotia near to the pseudostem and both were maintained with the field capacity condition. Third, the sclerotia were dispersed in the planted trays and maintained inundated condition till the experimental period. Observations were recorded after 10, 15 and 21 days after inoculation. We also evaluated the effect of medicinal plants leaf extract on mycelia growth and sclerotial production of S.oryzae. We observed that the, rice plant directly inoculated with sclerotia and sclerotia lying very adjacent to stem was found to be most favourable for infection moreover botanicals extracts of Karanj and Madar were highly effective in inhibiting the growth and sclerotial formation.

\section{Introduction}

Rice (Oryza sativa L.) is one of the major cereal crop in the world. At global level it occupies an area of $156.7 \mathrm{~m}$ ha. with total production of $650.2 \mathrm{mt}$. In India total rice grown on $43 \mathrm{~m}$ ha covering all the state having total production of $104.3 \mathrm{mt}$ and average productivity $21.30 \mathrm{q} / \mathrm{ha}$ though the varieties grown and area under this crop varies from state to state. Chhattisgarh state is popularly known as "'Rice bowl of India", because maximum area is covered under rice during kharif and contribute major share in national rice production. It has geographical area of $13.51 \mathrm{~m}$ ha of which $5.9 \mathrm{~m}$ ha under cultivation. Rice occupies an area of 3.7. $\mathrm{m}$ ha with the production of $6.15 \mathrm{~m} \mathrm{t}$ and productivity of $16.63 \mathrm{q} / \mathrm{ha}$ (Anonymous, 2012). Being a staple food crop, it occupies 
the status of record position next to the wheat feeding approximately $50 \%$ of the world population. In India also besides as a meal its recipes of different types (in snacks form) are also used in different ways. Rice is an integral part of the Indian culture also in addition to its food value. For countries GDP and also economy this crop is contributing lions share. Rice in India is grown under tropical and subtropical conditions starting from Kanyakumari to Kashmir and Assam to Gujarat. With the lapse of time rice also evolved itself and this country has rich germplasm source. Being grown as kharif (rainy season) crop it also cultivated in rabi (winter- summer) crop in some pockets of different states. In the irrigation rich belts like Godavari delta it is also taken as kharif, winter- 13 early summer and summer crops. This crop has the ability to grow under wide ecological conditions including less rain fall situation to inundated condition and submerged conditions. Further, it is also grown from calcareous, laterite soils, alluvial to black soils. The countries population has bulged to 125 crores approximately and with increase in residential areas the cultivable land gradually diminishing. There is tremendous pressure on staple food crops (rice and wheat) for maintaining production trend copying with the population growth. In this several scientific breakthroughs were also made by ways of development of hybrids and yield potential increase inbreeds through the intervention of novel methods.

With the limitations in the further exploitation of above intervention, the only option remaining with the scientific community is to minimize the yield losses due to pest and diseases and also in storage condition. Among the pest and diseases, different disease like bacterial blight, blast, sheath blight, sheath rot and stem rot were rated as most economically important. The stem rot caused by Sclerotium oryzaeis an important pathogen which has the ability to survive, infect and perpetuate from tripled cropped to single crop regions. Besides rice as a host it has ability to infect other crops also. The present studies were conducted to generate information/ confirmation of the important findings pertinent to this pathogen/ disease.

Therefore the following objectives were covered in the present study.

1. Studies on condition favouring infection of S. oryzae on selected rice germplasm.

2. In vitro efficacy of different chemicals/ biopesticides on $S$. oryzae.

Conditions favouring sclerotial propagules infection:

Weber (1931) recorded infection of carrot roots by $S$. rolfsii, appears to be the first report causing severe rotting in storage. Sulladmath et al., (1975) observed typical root rot symptoms in soil inoculated with $S$. roflsii after 30-35 days of oat seed sowing. The organism was re-isolated from such infected plants. Roy (1977) tested the pathogenicity of the $S$. roflsii on Pea (Pisumsativum L.), Cauliflower (Brassica oleracea var capitata L.) and found that rotting in all the cases was more than $50 \%$ in 4 to 5 days. Haware and Nene (1978) obtained 100 per cent germination in uninoculated pots of chickpea seeds. Fifty percent of the seeds in the inoculated treatment were failed to germinate. The causal fungus initiated the rotting of these seeds and the seed surfaces were covered with a white mycelial mat in the soil. The germinated seedling was killed within 7 days after emergence. Symptoms were evident as yellowing of leaves followed by seedling collapse. The affected roots sowed abundance of superficial wide fluffy mycelium. A semi watery decay at the collar region was evident. The pathogen was successfully re-isolated 
from the diseased plants. Siddaramiah et al., (1978) proved the pathogenicity by sowing 50 seeds which were artificially inoculated with 20 days old Corticium culture and the same quantity of the seed was sown in the sterilized soil as a control. Out of 50 seeds, 40 germinated and remaining 10 seeds did not germinate. The fungus started infection after the third day of seed germination and all the forty seedlings were infected within a week causing post-emergence death. In the case of control, 48 seeds germinated and there was no infection of the fungus based on the characteristics symptoms, the fungus was identified as C.rolfsii Curzi. Shokes and Gorbet (1998) observed stem and pod rot on groundnut by $S$. rolfsii with potential death and estimated field yield losses of $10 \%$ or more in the southern-eastern USA. Similarly, Blum and Rodriguez (2004) also recorded a reduction in seed germination and plant growth in soybean by $S$. rolfsii. Such similar results on the pathogenicity of $S$. rolfsii have also been reported on Edgeworthia papyrifera Taiwan from (Chang, 1994), maize and apple from Pakistan (Ahmed et al., 1984; Jahangir et al., 1995), Phaiusflavus and Paphiopedilum venustum from India (Bag, 2004) chilli from Malaysia (Jomduang, 1995) and apple from USA (Conway and Tomasino, 1985). Padole et al., (2009) investigated variations in 51 isolates of S.rolfsii sowed considerable variation with regards to cultural and morphological characters on 21 PDA medium. Based on these characters than broadly grouped into three pathotypes. The pathogenicity test sowed that those grouped also varied isolates in a number of days taken to initiate plant mortality and $100 \%$ mortality. Awasthy et al., (2010) investigated the pathogenicity of different isolate $S$. rolfsii Sacc. on groundnut. Observations revealed that all the isolates were found to be pathogenic towards groundnut but the extent of their pathogenicity in respect of their disease severity differed among the isolates.
Results also revealed a marked variation in the virulence of the different isolates. Isolate 10 show of their collection highest disease severity of $54.4 \%$ which was superior as compared to all other isolates. Whereas, Isolate 2 and Isolate 8 showed least diseases severity of 40 . And $40.9 \%$ respectively.

\section{Botanicals}

Daya and Ram (1992) tested extracts of 13 medicinal plants for their activity against collar rot of chickpea caused by S.rolfsii. The most effective disease control was by Hemidesmus indicus oil (100\%) followed by Dioscorea bulbifer ( $85 \%$ ) over control. Soil application of leaves of Azadirachta indica, rhizomes of Curcuma amada and resin of Ferula fostida at 5 per cent concentration reduced pre and post emergence mortality of chickpea caused by $S$. rolfsii was reported by Ram and Tewari (1994). Similarly the leaf extract of Tamarandus indica, Sopindustri folia and root extract of Moringa oleifera (Pani and Patra, 1997), Pithecellobium dulce and Vitex negundo (Meena and Muthusamy, 2002), stem extract of Cactus deficient (Zapata et al., 2003) significantly reduced the mycelial growth of $S$. rolfsii on PDA medium and 70 to 94 per cent reduction in disease incidence in sick pots. Gautam and Chauhan (2004) evaluated methanol extract $(40,200$ or $1000 \mu \mathrm{g} / \mathrm{ml}$ ) of 2222 plant species at 48, 60 and $72 \mathrm{hrs}$ intervals against $S$. rolfsii and stated that the growth reduction increased with extract concentration. Hanthagowda and Adiver (2001) tested different plants extract against $S$. rolfsii. Among them, 1:20 dilution of Parthenium hysterophorus, Polyalthia longifollia and Azadirachta indica significantly inhibited the mycelial growth of $S$. rolfsii. Pretorius et al., (2002) evaluated the extract of 39 plant species against the $F$. oxysporum, $S$. rolfsii and $R$. solani and found that the crude extract of Aristeaecklonii and Agapanthus inapertus completely inhibited 
the mycelial growth of above pathogens. Also in the vitro antifungal activity of bulb extract of Eucomis autumnalis was showed against above pathogens by Pretorius et al., (2002) and Eksteen et al., (2001). By using poisoned food technique, the antifungal activity of the volatile oil from the leaves of Eucalyptus citriodora against Macrophomina phaseolina, $F$. oxysporum, R.solaniand $S$. rolfsii was showed by Yossry et al., (1998) and Ramezani et al., (2002). Bhamare et al., (2003) found that plant extract of $E$. terticornuis, Malvapusila, Datura stramonium, Parthenium hysterophorus and Tgetus erecta reduced seed borne microflora (inducing species of Fusarium, Rhizoctonia and Sclerotium) of chickpea significantly and increased seed germination over untreated control. Tripathi et al., (2006) suggested that the radial growth of $S$. rolfsii was significantly less in leaf extract of Ashwagandha $(31.83 \mathrm{~mm})$ followed by Vana Tulsi $(35.86 \mathrm{~mm})$. The number of sclerotia was significantly less in leaf extract of Nirgudi, Ashwagandha, Vanulsi, Khamar followed by Sikakai and Japanese pudina compared to the control (162.00 sclerotia per plate). Venkateswarlu and Sreeramulu (2013) studied on in vitro efficacy of plant extracts at different concentration and reported that all the extracts showed a significant reduction in the growth of the pathogen. Fifteen medicinal plant extracts were evaluated by Venkateswarlu et al., (2013) against stem rot disease and concluded that the amendment of 2\% extract of Andrographis paniculata, Calotropis procera and Eucalyptus globules were found significantly more effective as an alternative to conventional chemical fungicides.

\section{Materials and Methods}

Studies on conditions favouring sclerotial propagules infection:
Sclerotia formed as structures under adverse conditions usually are the main source of primary inoculum after perpetuating till the other collateral or/and alternate hosts appearance in the vicinity. During the cultivation operation and monsoon period, the rice crop at the initial stage, comes a crosses some time and with the dry condition, saturated field condition, inundated conditions. Therefore, in the present study on a most popular susceptible variety (Swarna) widely grown in this region is selected for the study, to know the best conditions that favour the sclerotial infection after the perpetuation. The entire study was conducted in large metallic trays and glass house condition. Swarna was sown in lines in trays. After 25 days of germination the following treatments were applied; first, Plants were inoculated with one sclerotium per sheath by gently making an attachment with transparent tape piece and trays were maintained with field capacity condition. Second, the plants were placed with sclerotia very near to the pseudostem and trays were maintained with the field capacity condition. Third, the sclerotia were dispersed in the planted trays and maintained inundated condition till the experimental period. Observations recorded for the stem rot diseased seedlings after 10, 15 and 21 days.

In-vitro evaluation of medicinal plants leaf extract on mycelia growth and sclerotial production of S.oryzae.

Antifungal activity of ten medicinal plants leaf extracts was studied under in vitro condition by using respectively plant leaf dextrose agar medium. The following medicinal plants viz., Neem (Azadirachta indica), Datura (Datura stramonium), Karanj (Pongamiapinnata), Eucalyptus (Eucalyptus globulus), Lemongrass (Cymbopogo nfexuosus), Vana Tulsi (Hyptis suaveolens), Bel (Aegle marvellous), Madar (Calotropis 
procera), Alovera (Aloe vera), and Mint(Mentha sp.) and PDA alone served as control. The preparation of leaf extract medium was same as PDA medium. Twentygram leaves of each medicinal plant were taken in $100 \mathrm{ml}$ water and boiled till it became softened. Softened medicinal plant leaves were crushed in pestle and mortar, and then extract was filtered. $2 \mathrm{gm}$ dextrose and $2 \mathrm{gm}$ agar-agar were mixed in filtered leaf extracts and volume was made up to $100 \mathrm{ml}$ and sterilized in an autoclave. To avoid bacterial contamination, a pinch of Streptomycin sulphate was added at the time of pouring of media in Petriplate. About twenty $\mathrm{ml}$ media was poured in a sterilized Petriplate and allowed to solidify. A five $\mathrm{mm}$ disc from four days old culture of the test fungus was placed in the centre of the medium.

Three replications were maintained for each treatment along with a control. The inoculated Petriplates were then incubated in the BOD incubator at $30 \pm 1^{\circ} \mathrm{C}$. Observations were recorded for mycelial growth regularly after inoculation and sclerotia were counted 15 days after inoculation. Percent inhibition of mycelial growth was calculated by the following formula,

Inhibition $\%=\mathrm{C}-\mathrm{T} / \mathrm{C} \times 100$

Whereas $\mathrm{C}=$ Diameter of fungus colony $(\mathrm{mm})$ in control plate

$\mathrm{T}=$ Diameter of fungus colony $(\mathrm{mm})$ in treated plate

\section{Results and Discussion}

Conditions favouring sclerotial propagules infection:

Three types of inoculation methods viz. direct inoculation, inoculation near stem with field capacity and inoculated near stem with maintained inundated condition was studied to assess the most favourable condition for infection. In the direct inoculation method, the sclerotia were kept on the sheath of 10 days old seedlings. The infection started the 4th day after inoculation as browning of tissue of sheath region appeared. Leaves became dull and yellow and increased gradually day by day. However, 15 days after inoculation yellowing and drying become enlarged. Day by day the plants started drooping and continue till death. It looks about 17-19 days for complete death. In the direct method, the mortality percentage was recorded about $66.67 \%$ (Table 1). On the other hand, sclerotia kept on near the stem created with field capacity, the infection started too late as compared to a direct method and after 25 days of inoculation yellowing and drying with typical symptoms appearance.

Table.1 Condition favouring sclerotial propagules for infection

\begin{tabular}{|l|c|}
\hline & Percent diseased Plants \\
\hline Direct inoculation & 66.67 \\
& $(56.78)$ \\
\hline $\begin{array}{l}\text { Sclerotia kept on near stem with field } \\
\text { capacity condition }\end{array}$ & 56.67 \\
\hline Sclerotia kept on near stem with & $(46.92)$ \\
maintained inundated condition & 0.00 \\
\hline $\mathbf{S E m} \pm$ & $(4.05)$ \\
\hline $\mathbf{C D}(\mathbf{P}=\mathbf{0 . 0 5})$ & 1.11 \\
\hline
\end{tabular}


*Average of three replications

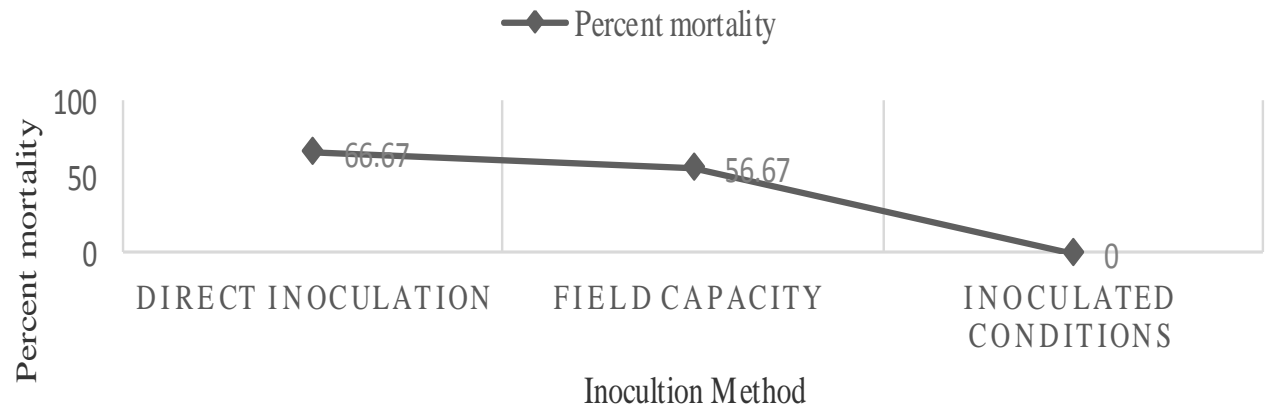

Table.2 Inhibitory effect of medicinal plant leaf extracts on mycelial growth and sclerotial production of S.oryzae

\begin{tabular}{|l|l|l|c|c|c|}
\hline S. no. & $\begin{array}{l}\text { Medicinal } \\
\text { plants }\end{array}$ & Botanical Name & $\begin{array}{l}\text { Radial growth } \\
(\mathbf{m m})\end{array}$ & $\begin{array}{l}\text { Inhibition } \\
(\mathbf{\%})\end{array}$ & $\begin{array}{l}\text { No. of } \\
\text { sclerotia } \\
\text { per plates }\end{array}$ \\
\hline $\mathbf{1}$ & Vamtulsi & Hyptissuaveolens & 76.17 & $\begin{array}{c}15.36 \\
(23.04)\end{array}$ & 198 \\
\hline $\mathbf{2}$ & Lemongrass & Cymbopoganflexosus & 56.67 & $\begin{array}{c}37.03 \\
(37.48)\end{array}$ & 102 \\
\hline $\mathbf{3}$ & Neem & Azadirachtaindica & 57.17 & $\begin{array}{c}36.48 \\
(37.15)\end{array}$ & 57 \\
\hline $\mathbf{4}$ & Karanj & Pongamiapinnata & 44.33 & $\begin{array}{c}50.74 \\
(45.42)\end{array}$ & 143 \\
\hline $\mathbf{5}$ & Madar & Calotropisprocera & 52.33 & $\begin{array}{c}41.85 \\
(40.28)\end{array}$ & - \\
\hline $\mathbf{6}$ & Bel & Aegle marmolus & 63.00 & $\begin{array}{c}30.00 \\
(33.19)\end{array}$ & 103 \\
\hline $\mathbf{7}$ & Eucalyptus & Eucalyptus globules & 61.83 & $\begin{array}{c}31.29 \\
(33.99)\end{array}$ & 121 \\
\hline $\mathbf{8}$ & Alovera & Aloe vera & 66.00 & $\begin{array}{c}26.66 \\
(31.07)\end{array}$ & 99 \\
\hline $\mathbf{9}$ & Datura & Datura stamonium & 67.00 & $\begin{array}{c}25.55 \\
(30.27)\end{array}$ & - \\
\hline $\mathbf{1 0}$ & Mint & Menthe sp. & 82.17 & $\begin{array}{c}8.70 \\
(16.04)\end{array}$ & 284 \\
\hline $\mathbf{1 1}$ & Control & & 90.00 & $\begin{array}{c}0.00 \\
(4.05)\end{array}$ & 182 \\
\hline & SEm \pm & & 1.76 & 1.31 & \\
\hline & CD(P=0.05) & & 5.17 & 3.84 & \\
\hline
\end{tabular}

*Average of three replications.

- = no sclerotia formation 


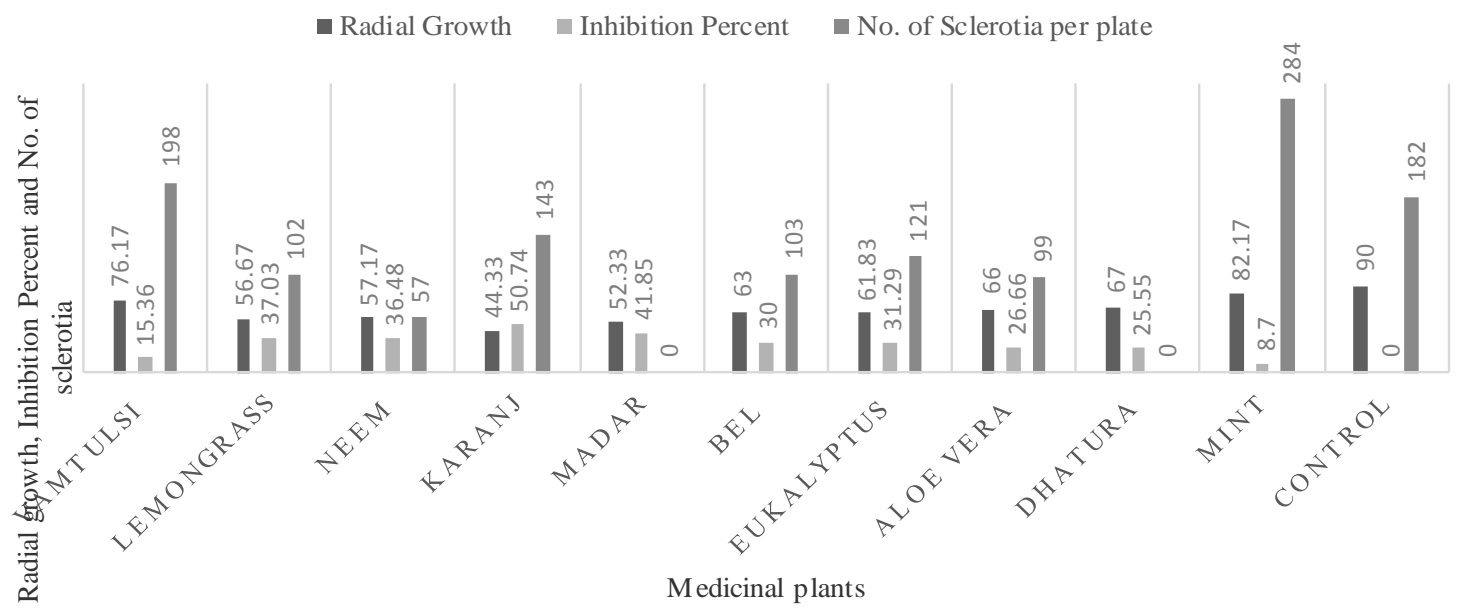

Plants look 27-35 days for complete death. In this method, the mortality percentage was less $(56.67 \%)$ as compared to the direct method. Similar results were reported by Rajalakshmi (2002). But in the last condition where inundated condition was maintained no any symptoms were observed till the study period of 40 days might be due to some other reason including failing to get in touch with the surface of the host.

In-vitro evaluation of medicinal plants leaf extract on mycelial growth and sclerotial production of S. oryzae.

Antifungal activity of 10 different medicinal plant leaf extracts was studied in-vitro and the results were presented in Table 2. Data from the table indicates that Karanj (50.74\%) was most effective in inhibiting the mycelial growth of $S$. oryzae followed by Madar $(41.85 \%)$ followed by Lemongrass, Neem, Eucalyptus, Alovera, Datura, Vamtulsi and Mint. All the leaf extracts could inhibit the pathogen over control significantly.

The sclerotial formation was completely absent in Madar, Datura and the lowest number of sclerotia were recorded in Neem leaf extract followed by Alovera and Lemongrass while higher sclerotial production was observed in the extract of Mint and Tulsi as compared to control. The percent finding was also supporting the earlier report Daya and Ram (1992); Hanthegowda and Adiver (2001); Anand et al., (2003); Bhosale (2003) and Tripathi (2004). Leaf extract of Neem was found to be the best as reported by Singh et al., (2007); Patil and Rout (2008) and Mundhe et al., (2009).

In conclusion, the rice plant directs inoculated with sclerotia and sclerotia lying very adjacent to stem with a field capacity condition was found to be most favourable for infection. The botanicals extracts Karanj and Madar were highly effective in inhibiting the growth and sclerotial formation.

\section{References}

Ahmed, Y., M.S. Mirza and M. Aslam. 1984. Sclerotium rolfsii on maize. FAO Plant Prot. Bull., 32: 147.

Anand, A.K., More, N.K.S. and Lal, R.J. 2003. Effect of leaf extract of some botanicals on mycelium growth and sclerotial production of Sclerotium 
rolfsii. Indian Phytopath. 56 (3): 360.

Awasthi, D. P., Dasgupta, B. and Das, S. 2010. Pathogenicity test of different isolates of Sclerotium rolfsii Sacc. on stem rot of groundnut (Arachis hypogaea L.). Environment and Ecology. 28(1): 152-153.

Bag, T. K. 2004. Two new orchid hosts of Sclerotium rolfsii from India. Plant Pathol. 53: 255.

Bhamare, V.J., Awadhiya, G.K. and Lakpale, N. 2003. Effect of the volatile compound and plant extract on seedborne microflora and germination of chickpea. In: Chickpea Research for the Millenium. International Chickpea Conference, Raipur, Chhattisgarh, Jan. 20-22. pp 172-176.

Bhosale, P.M. 2003. Studies on management strategies of collar rot of linseed (Linumusitatissinum L.) caused by Sclerotium rolfsii M.Sc. (Agri.) Thesis submitted to the I.G.K.V.

Blum, L.E.B. and R. Rodriguez-Kabana. 2004. Effect of organic amendments on sclerotial germination, mycelial growth, and Sclerotium rolfsii induced diseases. FitopatologiaBrasileira, 29: 66-74.

Chang, T. 1994. Pathogenicity of Sclerotium rolfsiion Edgeworthiapapyriferaand sclerotial 84 survival. Bull Taiwan For. Res. Inst. New Series 9: 191-196.

Conway, K.E. and S.F. Tomasino. 1985. Sclerotium rolfsii, a problem to apple nursery stock in Oklahoma. Phytopathol., 75: 499.

Curzi, M. 1931. Studisulo Sclerotium rolfsii. Bull. Staz. Pathol. Vegetable, M. S. 11: 306-373.

Daya Ram and Ram, D. 1992. Effect of decamping medicinal plants on chickpea (Cicer arietinum L.) collar rot caused by Sclerotium rolfsii. Ann. Biol. 8(1): 91-94.

Eksteen, D., Pretorius, J. C., Nieuwoudt, T. D. and Zietsman, P. C. 2001. Mycelial growth inhibition of plant pathogenic fungi by extracts of South African plant species. Ann. Appl. Biology. 139(2): 243-249.

Gautam, K. and Chauhan, S.V.S. 2004. Fungicidal properties of some plants of family Asteraceae against Sclerotium rolfsii. Ann. Pl. Prot. Sci. 12 (1): 207208.

Hanthegowda, B. and Adiver, S. S. 2001. Effect of plant extracts, bio agents, rotational crops and their root exudates on Sclerotium rolfsii causing stem rot of groundnut. GAU Res. J. 18(2): 240-243.

Haware, M. P. and Nene, Y. L. 1978. A root rot of chickpea seedlings caused by a sterile fungus Legume Research. 1(2): 65-68.

Jahangir, A. M., Mohibullah, M. K., Ayub, M. and Khan, M. 1995. Detection of fungi causing root rot of apple nurseries in Swat. Sarhad J. Agri. 11.754-748.

Jomduang, J. 1995. Evaluation of Malaysian isolates of Trichoderma harzianumand Gliocladium virensfor the biological control of Sclerotium foot rot of chilli. Thesis Dissertation, Department of Plant Protection, University Putra Malaysia.

Meena, B. and Muthusamy, M. 2002. Fungitoxic properties of plant extract against Sclerotium rolfsii in jasmine. J. Ornamental Horticulture New Series. 5 (1): 82- 83.

Mundhe, V.G., Diwakar, M.P., Kadam, J.J., Joshi, M.S. and Sawant, U.K. 2009. In vitro evaluation of bio-agents and botanicals against Sclerotium rolfsii causing foot rot of Fingermillet (Nagli). J. Pl. Dis. Sci. 4 (2): 183-186.

PadoleSachin, Om Gupta and Madhuri Mishra 2009. Variability among isolates of Sclerotium rolfsiiSacc. causing collar rot of chickpea. Journal of Food Legumes. 22(2):127-130.

Pani, B. K. and Patra, A. K. (1997). 
Utilization of some phytoextracts of $S$. rolfsii during paddy straw mushroom cultivation a new approach. Mushroom Res., 6(1): 37-41.

Patil, S.K. and Raut, S.P. 2008. Efficacy of fungicides, bio-agents and botanicals against collar rot of betelvine. $J$. Pl. Dis. Sci.3 (1):93-96.

Pretorius, J. C., Craven, P. and Watt, E. 2002b. In vivo control of Mycosphaerella pinodes on pea leaves by a crude bulb extract of Eucomis autumnalis. Ann. Appl. Biology. 141(2): 125-131.

Rajalakshmi. 2002. Studies on variability among the isolates of Sclerotium rolfsiiSacc. M.Sc. (Agri.) Thesis submitted to Acharya N.G. Ranga Agricultural University, Hyderabad (A.P.).

Ram, D. and Tewari, V.P., 1994, Control of chickpea collar rot (Sclerotium rolfsii) with soil application of plant products. Journal of Applied Biology, 4(112): 33 40.

Ramezani, H., Singh, H.P., Batish, D.R. and Kohli, R.K. 2002. Antifungal activity of the volatile oil of Eucalyptus citriodora. Fitoterapia. 73 (3): 261-262.

Roy, A. K. 1977. Attack of Sclerotium rolfsiion some plants and capability of the fungus to cause storage rot. Indian Phytopath. 30 (1): 425-426.

Shokes, F. and Gorbet, D. 1998. Crop losses due to stem rot of groundnut in commercial cultivars and partially resistant breeding lines. ICPP 98 pp. 35.

Siddaramaiah, A. L., Kulkarni, S. and
Basavarajaiah, A. B. 1978. The occurrence of a new collar rot disease of niger (Guizotia abyssinica Cass.). Curr. Sci. 45 (7): 74.

Singh, S.R., Prajapati, R.K., Srivastava, S.S.L., Pandey, R.K. and Gupta P.K. 2007. Evaluation of different botanicals and non-target pesticides against Sclerotium rolfsii causing rot of lentil. Indian Phytoath. 60 (4): 499-501.

Sulladmath, V. V., Kumar, A. T. B. and Hiremath, P. C. 1975. Foot rot of oats caused by Sclerotium rolfsii. Curr. Sci. 44(24): 907.

Tripathi, B.P. 2004. Study on Sclerotium rolfsiiSacc. causing collar rot of chickpea. M. Sc. (Agri.) Thesis submitted to the I.G.K.V.

Tripathi, B.P. and Khare, N. 2006. Testing of fungicide against Sclerotium rolfsii. J. Mycol. Pl. Pathol. 36 (2): 347-348.

Venkateswarlu, N. and Sreeramlulu, A. 2013. In vitro evaluation of selected plants extracts on the mycelial growth of Sclerotium oryzae Catt. International Journal of Pharma and Bio-Science 4(2): (B) 640-644.

Weber, G.F. 1931. The blight of carrots caused by Sclerotium rolfsii, with geographic distribution and host range of the fungus. Phytopathol., 21: 11291140.

Yossry, A.A., El All, S.M.A. and El Imery, S.M. 1998. Fungi toxic properties of some plant extract against the growth of soil-borne disease fungi. Ann. Agril. Sci. Egypt. Special Issue. 3: 891-909.

\section{How to cite this article:}

Vandana Sahu and Thrimurthy, V.S. 2019. Studies on Conditions Favouring Sclerotial Propagules Infection and Effect of Botanical Extracts on its Production and Growth in Sclerotium oryzae. Int.J.Curr.Microbiol.App.Sci. 8(08): 1660-1668. doi: https://doi.org/10.20546/ijcmas.2019.808.196 